\title{
THE IMPLICATIONS OF A SUPREME LAW BILL OF RIGHTS FOR NEW ZEALAND JUDICIAL APPOINTMENTS
}

\author{
Juliet Bull*
}

The enactment of a supreme law Bill of Rights in New Zealand would have significant implications for the process of appointing judges. This article considers whether the present judicial appointments system should be retained were New Zealand to amend the New Zealand Bill of Rights Act 1990 to have supreme law status. It contends that the present appointments process is insufficiently transparent and offers too few checks and balances to safeguard the apolitical nature of appointments. Canada's experience after enacting the Canadian Charter of Rights and Freedoms is drawn upon to demonstrate the need for reform. After various options are considered, it is ultimately contended that the adoption of a supreme law Bill of Rights in New Zealand should be accompanied by the creation of a judicial appointments commission.

\section{INTRODUCTION}

If New Zealand were to enact a supreme law Bill of Rights, giving judges the power to invalidate legislation that is inconsistent with fundamental rights and freedoms, the judiciary would become a more powerful branch of government with judges more prominently involved in political and policy disputes. This article examines whether the present system of appointing judges would remain fit for purpose - whether it is sufficiently transparent and democratic, and whether it would effectively safeguard judicial independence - were judges to take on this new and wider power.

After considering how the role of judges would be altered by a supreme law Bill of Rights and what is meant by the oft-stated charge that judicial appointments will subsequently become politicised, this article then examines New Zealand's present system of appointments. The integrity of key actors is shown to be the primary safeguard against improperly political appointments. Drawing on Canada's experience after the Canadian Charter of Rights and Freedoms (the Charter) ${ }^{1}$

* Submitted as part of the LLB(Hons) programme at Victoria University of Wellington.

1 Canadian Charter of Rights and Freedoms, art 7 (pt 1 of the Constitution Act 1982, being sch B to the Canada Act 1982 (UK)). 
was enacted, it is contended that the existing appointments system should not be retained if a supreme law Bill of Rights is adopted. The Canadian experience provides several insights as to how reform of judicial appointments should be undertaken.

Given the conclusion that change is needed, the final parts of this article evaluate the advantages and disadvantages of various options for reform. This analysis illustrates tensions that exist between several of the goals that reform of judicial appointments seeks to achieve. Ultimately, if a supreme law Bill of Rights is to be enacted, it is contended that an appointments commission which recommends a shortlist of candidates from which the Attorney-General selects who to appoint should be adopted.

\section{A SUPREME LAW BILL OF RIGHTS FOR NEW ZEALAND}

The New Zealand Bill of Rights Act 1990 (NZBORA) has influenced both the law-making process, by requiring that the Attorney-General report to the House of Representatives on whether a Bill is inconsistent with the Act, ${ }^{2}$ and statutory interpretation, by mandating that judges interpret statutes in a manner consistent with the protected rights. ${ }^{3}$ Despite its substantial influence, the original proposal went much further with an entrenched Act of supreme law status, ${ }^{4}$ permitting courts to invalidate legislation inconsistent with the Act. Although this attracted opposition at the time, there remains a sense of unfinished business and the possibility that New Zealand will eventually amend the Act to have supreme law status. Sir Geoffrey Palmer referred to the "constitutional caravan" moving on in suggesting that the time may have come for this reform to occur. $^{5}$

This article does not address the desirability of that reform, a matter which has been the subject of extensive academic debate. Instead, it assumes that a supreme law Bill of Rights is to be adopted and addresses a collateral matter that has not received academic attention: the implications of a supreme law Bill of Rights for New Zealand's system of appointing judges. To assess this issue, it is assumed that NZBORA in its present form would be amended to have supreme law status. Therefore the same rights and freedoms as presently protected would be upheld as higher law. ${ }^{6}$

2 New Zealand Bill of Rights Act 1990, s 7. These reports can be found on the Ministry of Justice website <www.justice.govt.nz>.

3 New Zealand Bill of Rights Act 1990, s 6. For further discussion see JF Burrows and RI Carter Statute Law in New Zealand (4th ed, LexisNexis, Wellington, 2009) at 332-383.

4 See Geoffrey Palmer "A Bill of Rights for New Zealand: A White Paper" [1984-1985] I AJHR A6.

5 Geoffrey Palmer "The Bill of Rights After Twenty-One Years: The New Zealand Constitutional Caravan Moves On?" (2013) 11 NZJPIL 257.

6 There has been significant academic commentary on whether additional rights should be protected within the Act, but this is outside the scope of this article. See, for example, the argument of Butler and Butler on the protection of social and economic rights, property rights and the right to privacy: Andrew Butler and 


\section{A What Would Change?}

The fundamental change brought by a supreme law Bill of Rights is the ability of courts to strike down laws that are repugnant to the rights contained within it. In determining whether to invalidate legislation, courts would consider whether the breach of rights was "demonstrably justified in a free and democratic society". ${ }^{7}$ This section assesses the significance of that new power for New Zealand's judges.

There are some reasons to think this reform would not significantly alter judges' powers. Judges are already generally bolder and more willing to develop the law than in the past. ${ }^{8}$ Moreover, the rights protected by NZBORA are generally procedural rather than substantive. This, Sir Kenneth Keith suggests, goes some way toward avoiding the difficulties associated with unconfined rights like an equal protection clause - that give judges greater scope to second guess policy decisions of the executive and legislature. ${ }^{9}$

Nonetheless, a supreme law Bill of Rights is still likely to have a substantial impact on the role of New Zealand's judges. Enactment of the Charter has had significant implications for the Canadian judiciary: former Chief Justice Antonio Lamer said "the Charter has changed our job descriptions", ${ }^{10}$ forcing judges to make what were formerly political decisions. ${ }^{11}$ Chief Justice Beverly McLachlin expressed similar sentiments, saying that the Charter forced courts "to grapple with a whole range of hitherto unlitigable issues, many of them involving social and moral questions of profound importance and difficulty". ${ }^{12}$ Examples of major Canadian Charter cases include striking down a reverse onus provision; ${ }^{13}$ striking down a provision criminalising abortion; ${ }^{14}$ and

Petra Butler "Protecting Rights" in Caroline Morris, Jonathan Boston and Petra Butler (eds) Reconstituting the Constitution (Springer-Verlag, Berlin, 2011) 157.

7 New Zealand Bill of Rights Act 1990, s 4.

8 Geoffrey Palmer "Judicial Selection and Accountability: Can the New Zealand System Survive" in BD Gray and RB McClintock (eds) Courts and Policy: Checking the Balance (Brookers, Wellington, 1995) 11 at 16-17. This is demonstrated, for example, through the interpretation of constitutional documents as living texts and developments in judicial review of administrative action.

9 KJ Keith "A Bill of Rights for New Zealand: Judicial Review versus Democracy" (1985) 11 NZULR 307 especially at $315-316$

10 James WStG Walker "Race," Rights and the Law in the Supreme Court of Canada (Wilfrid Laurier University Press, Waterloo (ON), 1997) at 325

11 FL Morton "Judicial Recruitment and Selection" in FL Morton (ed) Law, Politics and the Judicial Process in Canada (3rd ed, University of Calgary Press, Calgary, 2002) 117 at 128.

12 BM McLachlin "The Charter: A New Role for the Judiciary" (1991) 29 Alta L Rev 540 at 543.

$13 R$ v Oakes [1986] 1 SCR 103.

$14 R v$ Morgentaler [1988] 1 SCR 30. 
decisions on gay rights ${ }^{15}$ and euthanasia. ${ }^{16}$ It is foreseeable that cases could emerge on similarly prominent and controversial issues in New Zealand.

Commentators recognise that a supreme law Bill of Rights might necessitate changes to the appointments system. For example, a Chen Palmer report for then Attorney-General Margaret Wilson said that, were New Zealand to adopt this reform, "a different approach to the role of the Executive in the appointment and removal of judges might be a necessary consideration as part of wider constitutional reform". ${ }^{17}$

The issue is whether the present appointments system will remain fit for purpose once judges have new and significantly wider powers. Will the system enhance public confidence in the independence of the judiciary and judges' suitability to decide Bill of Rights cases? Is the process sufficiently transparent and inclusive so as to avoid the perception of a democratic deficit, a heightened risk given the transfer of power from Parliament to judges? One oft-stated concern is that a supreme law Bill of Rights increases the risk that governments will improperly appoint judges for political reasons, to ensure that the courts will uphold the government's values and not overturn its legislative achievements. The next section examines what is meant by the concern that appointments will be politicised.

\section{B Politicised Judicial Appointments}

The judiciary's independence is a fundamental element of the rule of law. ${ }^{18}$ While some mechanisms, like security of tenure and the prohibition on salary reductions, uphold judicial independence by protecting sitting judges from improper influence, this value must also be protected via the appointments process. As the Economist editorialised, "the independence of the judiciary depends on the way judges are selected". ${ }^{19}$ There is little literature examining precisely what is meant by the concept of "politicised judicial appointments". Some commentators treat the general increase in the power of the courts vis-à-vis the legislature and the perception of "activist

15 Vriend v Alberta [1998] 1 SCR 493.

16 Carter v Canada 2015 SCC 5, [2015] 1 SCR 331.

17 Chen Palmer \& Partners "Memorandum to the Hon Margaret Wilson, Attorney-General: Judicial Administration Issues" (1 November 2002) at [55].

18 Philip A Joseph Constitutional and Administrative Law in New Zealand (4th ed, Brookers, Wellington, 2014) at 797.

19 "Who Judges the Judges?" The Economist (London, 15 November 2003) at 11, as cited in Peter McCormick "Selecting the Supremes: The Appointment of Judges to the Supreme Court of Canada" (2005) 7 J App Prac \& Process 1 at 28. Also see Martin L Friedland "Appointment, discipline and removal of judges in Canada" in HP Lee (ed) Judiciaries in Comparative Perspective (Cambridge University Press, Cambridge, 2011) 46 at 51 . 
judges" as evidence of politicisation. ${ }^{20}$ However, the focus here is on accusations that judicial appointments - not the role of judges generally - may become politicised.

It is clear that judicial appointments should not be made on the basis of a candidate's political affiliation or membership of a particular political party. Rewarding or punishing a candidate for this reason is undesirable. ${ }^{21}$ This issue is sidestepped to an extent in New Zealand where it would likely be considered inappropriate for a former Member of Parliament or prominent member of a political party to be appointed a judge.

Concerns about politicisation go beyond party politics, but it is here that drawing clear lines about what should and should not be permissible becomes difficult. Judicial appointments will always possess some element of politics in its broadest sense. Sir Robin Cooke said that appointments by the executive are "inevitably political to a greater or lesser degree". ${ }^{22}$ Graham Gee similarly suggests it would be impossible to remove the political dimension from appointments given that the process shapes the courts' ability to hold political institutions to account. ${ }^{23}$

When Palmer explained the characteristics he sought in judges as "forward-looking people of high intellectual ability, equipped with ample legal learning, experienced, practical, and able to bring essential human qualities to the administration of the law", he recognised that these factors may be perceived by some as political considerations. ${ }^{24}$ It is however impossible, and moreover undesirable, to attempt to remove these sorts of considerations from the appointments process. In contrast, an inappropriately political appointment would be based on a prospective judge's personal views on specific issues that may arise before the courts, or anticipation of how the candidate would decide particular cases. Drawing on an example from the United States, the "litmus test" purportedly adopted to check a candidate's position on abortion is an example of an inappropriately political enquiry into how a judge would approach a particular issue.

There is a further need to avoid candidates who are driven by ideology. The decision maker's general sense about the extent the judge will defer to Parliament is broadly political, but also likely

20 See for example Brian Galligan and Peter Russell "The Politicisation of the Judiciary in Australia and Canada" (1995) 67(2) The Australian Quarterly 85.

21 See Kate Malleson "The New Judicial Appointments Commission in England and Wales: New Wine in New Bottles" in Kate Malleson and Peter H Russell (eds) Appointing Judges in an Age of Judicial Power: Critical Perspectives from around the World (University of Toronto Press, Toronto, 2006) 39 at 41.

22 Robin Cooke "Empowerment and Accountability: The Quest for Administrative Justice" (1992) 18 CLB 1326 at 1331 .

23 Graham Gee "The Politics of Judicial Appointments in Canada" in Judicial Appointments: Balancing Independence, Accountability and Legitimacy (Judicial Appointments Commission, 2010) 99 at 99.

24 Geoffrey Palmer Reform (Victoria University Press, Wellington, 2013) at 302. For a similar perspective in the United Kingdom context see Jack Straw Aspects of Law Reform: An Insider's Perspective (Cambridge University Press, Cambridge, 2013) at 57. 
arises in the context of assessing the quality of his or her previous judgments and could not be removed from consideration. What must be avoided, however, are appointments based on a demonstrated track record of ideologically driven decisions. This record could be one of an unduly black letter and conservative approach to interpretation, systematic opposition to striking down laws in favour of extreme deference to Parliament, or a record of excessive activism and eagerness to find grounds on which laws can be invalidated. A candidate's record may be shown through their judgments or, in the case of new appointments to the bench, their conduct and writing while in practice. $^{25}$

In summary, a politicised appointment is one that takes into account party politics and a candidate's position on political issues and, more broadly, a decision that is made in anticipation of how the judge would decide particular cases before them. The system of appointments must guard against the government's ability to stack a court with ideologically driven candidates.

\section{JUDICIAL APPOINTMENTS IN NEW ZEALAND}

At present the Attorney-General is responsible for making judicial appointments. This part explains the process typically adopted by Attorneys-General and explores the strengths and weaknesses of this system.

\section{A Present System of Appointments}

Before the 1990s, New Zealand's appointments process was frequently criticised for lacking transparency. Described as "a highly discreet search process", ${ }^{26}$ it was "shrouded in secrecy and mystery". ${ }^{27}$ There were no published criteria for judicial office, expressions of interest were not called for, vacancies were not advertised, no interviews of candidates occurred and consultation processes were ad hoc. ${ }^{28}$

Some members of the legal profession supported this highly secretive system. From this perspective, the position's prestige required that the office should seek out the best occupants, rather than would-be occupants seeking judicial office; advertising and calling for applications "diminish[ed] the status of the office and thus its attraction as the pinnacle of a legal career". ${ }^{29}$ This

25 See Dyson Heydon "Judicial Activism and the Death of the Rule of Law" (2003) 47 Quadrant 9, a speech that was later referred to in jest as Heydon's "job application" because he was appointed shortly after its delivery to the High Court of Australia. For further discussion of this speech in the context of lobbying for appointment see David AR Williams "The Judicial Appointment Process" [2004] NZ L Rev 39 at 62.

26 John McGrath "Appointing the Judiciary" [1998] NZLJ 314 at 316.

27 Philip A Joseph "Appointment, discipline and removal of Judges in New Zealand" in HP Lee (ed) Judiciaries in Comparative Perspectives (Cambridge University Press, Cambridge, 2011) 66 at 66.

28 At 68.

29 See McGrath, above n 26, at 316 for a discussion and critique of this perspective. 
position, which enhances the perception that judicial appointments are insular and based on shoulder-tapping, has not prevailed. Instead, greater standardisation developed following a 1999 review and since then the process has featured appointment criteria, a clarified consultation process and a system of calling for expressions of interest. ${ }^{30}$

Despite increased standardisation, very few statutory provisions regulate judicial appointments. The Judicature Act 1908 provides that "Judges of the High Court shall be appointed by the Governor-General in the name and on behalf of her Majesty". ${ }^{31}$ Judges must have held a practising certificate as a barrister or solicitor for at least seven years, ${ }^{32}$ although most have had at least $15-20$ years of legal experience before their appointment. ${ }^{33}$ Shortlisted candidates must undertake not to resume legal practice upon retiring as a judge. ${ }^{34}$

The Governor-General appoints judges on the advice of the Attorney-General. Although the procedure adopted by a particular Attorney-General is prescribed neither by statute nor regulation, successive Attorneys have adopted broadly similar processes. ${ }^{35}$ In 2013 Attorney-General Hon Christopher Finlayson MP published a protocol setting out procedures and criteria for High Court appointments, described below. ${ }^{36}$

Prospective candidates may submit an expression of interest form, which is called for by public advertisement, or may be nominated during the consultation process. Candidates must provide a curriculum vitae and a declaration on issues like their health and financial position. ${ }^{37}$ The Judicial Appointments Unit, part of the Ministry of Justice, provides administrative assistance throughout

30 Patrick McCabe "Appointing Judges" [2004] NZ L Rev 244 at 244.

31 Judicature Act 1908, s 4(2).

32 Judicature Act 1908, s 6. Also see District Courts Act 1947, s 5(3).

33 Ministry of Justice Appointing Judges: A Judicial Appointments Commission for New Zealand? A Public Consultation Paper (April 2004) at 13

34 Joseph, above n 27, at 69.

35 James Allan "Judicial Appointments in New Zealand: If it were done when 'tis done, then 'twere well it were done openly and directly" in Kate Malleson and Peter H Russell (eds) Appointing Judges in an Age of Judicial Power: Critical Perspectives from around the World (University of Toronto Press, Toronto, 2006) 103 at 105.

36 See Crown Law Office High Court judges appointment protocol (April 2013, updated April 2014). Other former Attorneys-General and Solicitors-General have summarised the processes adopted while they were in office. See from former Attorneys-General: Palmer, above n 8, at 41-52; Paul East "A Judicial Commission" [1995] NZLJ 189 at 189-190; and Margaret Wilson "Appointing Judges the New Zealand Way" (2014) 21 Wai L Rev 41 at 46-47. See from former Solicitors-General: McGrath, above n 26, at 314 315; and Terence Arnold, Solicitor-General "Judicial Appointments" (Speech to the New Zealand Bar Association Conference, Wellington, 21 August 2003) at 2-3.

37 Crown Law Office, above n 36, at Appendix 2. 
the process and holds a confidential database containing the names of those who have expressed interest and are qualified for appointment. ${ }^{38}$

The Solicitor-General seeks comment on the candidates from a range of people and organisations and asks the Chief Justice, President of the Court of Appeal and the Chief High Court Judge to give all prospective candidates a rating. ${ }^{39}$ A long-list is created and presented to the Attorney-General containing those considered suitable for immediate appointment, those possibly suitable in two to three years and those in neither category.

For an upcoming vacancy, the Attorney-General, after completing the consultation he or she believes necessary and with the agreement of the Chief Justice, will determine a shortlist of no more than three names from which interviews conducted by the Attorney-General or Solicitor-General may occur. ${ }^{40}$ The Attorney-General will select one candidate from the shortlist, mention the appointment in Cabinet and formally advise the Governor-General to make the appointment. ${ }^{41}$ The shortlisting process is repeated for each upcoming High Court vacancy or appointment.

District Court appointments follow a similar process. The most significant difference is that a panel conducts interviews of shortlisted candidates. ${ }^{42}$ This panel consults with the Solicitor-General and the President of the Law Society before making its recommendation to the Attorney-General. ${ }^{43}$ Court of Appeal and Supreme Court appointments typically occur through judicial promotion and although appointment directly from the profession is permitted for both courts,${ }^{44}$ this rarely occurs for Court of Appeal appointments and has never occurred for the Supreme Court. ${ }^{45}$ Again there is little direction from legislation.

There are two primary exceptions to the process outlined above. The Minister of Māori Affairs recommends the appointment of judges to the Māori Land Court ${ }^{46}$ and the Prime Minister

38 Joseph, above n 27, at 68 .

39 Crown Law Office, above n 36, at 4-5.

40 Crown Law Office, above n 36, at 5.

41 See ss 4(2) and 57(2) of the Judicature Act 1908 and s 17 of the Supreme Court Act 2003.

42 Ministry of Justice Judicial Appointments: Office of the District Court Judge (August 2012) at 6. The panel comprises the Chief District Court Judge, the relevant Head of Bench, the Executive Judge for the region and a representative of the Ministry of Justice.

43 At 6 .

44 Judicature Act 1908, s 57; and Supreme Court Act 2003, s 20.

45 Joseph, above n 27, at 69.

46 See Te Ture Whenua Māori Act (Māori Land Act) 1993, s 7(2A), which requires that Māori Land Court judges have knowledge of te reo Māori, tikanga Māori and the Treaty of Waitangi. 
recommends the appointment of the Chief Justice. The Law Commission recently expressed approval of this exception, ${ }^{47}$ and the Prime Minister's role is to be codified. ${ }^{48}$

\section{$B$ Advantages and Disadvantages}

In assessing the advantages and disadvantages of the present system of appointments, this section pays particular attention to its ability to safeguard political neutrality in appointments. This is because the primary disadvantages of the present system are the lack of transparency and few formal checks and balances that limit the Attorney-General's exercise of discretion.

Widespread consultation is a key feature of the present process. Those consulted include senior judges (the Chief Justice, President of the Court of Appeal and Chief High Court Judge); organisations representative of lawyers (including the Presidents of the Law Society and Bar Association, and possibly the Māori Law Society and women lawyers' associations); senior politicians (including the Ministers of Justice, Women's Affairs and Māori Affairs, and possibly the Justice and Electoral Select Committee chairperson and shadow Attorney-General) and others like the President of the Law Commission. ${ }^{49}$ This consultation seeks to gather a diverse group of candidates and particularly to find individuals whose career and background are not reflected in the present judiciary ${ }^{50}$ Further consultation with a smaller group occurs as the Solicitor-General seeks comment on prospective candidates. The involvement of the shadow Attorney-General, a recently emerging practice, has been described as a "symbolic endorsement of the apolitical nature of appointments". ${ }^{1}$ However, the protocol produced by Mr Finlayson suggests that the shadow Attorney-General "may" be consulted when nominations are sought, suggesting this practice is not firmly established. ${ }^{52}$

An important feature of this process is the high level of judicial involvement. The most recent protocol outlined by Mr Finlayson suggests the Chief Justice has a veto power because the shortlist is created "with the agreement of the Chief Justice". ${ }^{53}$ Commentators including Palmer have been critical of appointments processes that gives judges a veto power. ${ }^{54}$ Then Solicitor-General John

47 Law Commission Review of the Judicature Act 1908: Towards a New Courts Act (NZLC R126, 2012) at recommendation 13. Also see [5.11].

48 Judicature Modernisation Bill 2013 (178-2), cl 100.

49 Crown Law Office, above n 36, at 6. Also see McGrath, above n 26, at 314; and Arnold, above n 36 , at 3.

50 See East, above n 36, at 191; and McGrath, above n 26, at 314

51 Joseph, above n 27, at 68 .

52 Crown Law Office, above n 36, at 6.

53 Crown Law Office, above n 36, at 5.

54 Palmer, above $\mathrm{n} 8$, at 43. 
McGrath QC's comment that the judiciary's role is consultative and that its input does not tightly restrict who may be chosen suggests that a judicial veto is not a firmly established rule. ${ }^{55}$ This inconsistency demonstrates one of the system's drawbacks; the absence of a firm statutory footing permits ad hoc procedures that lack transparency, notwithstanding efforts to standardise the process.

Judicial influence is counterbalanced by the Attorney-General having the final say over appointments, which is seen as having two benefits. First, giving the Attorney-General discretion is appropriate because he or she has the democratic mandate as a member of a government that enjoys Parliament's support; and secondly, this discretion is said to have encouraged the appointment of lawyers with diverse backgrounds in the law. ${ }^{56}$

The principal disadvantage of this system is the lack of formal safeguards to limit the AttorneyGeneral's exercise of discretion. Two main bulwarks protect the political neutrality of appointments: first, the conventions that govern the Attorney-General's decision making; and secondly, the fact that political pressures hold the Attorney-General accountable. The strength of these protections is evaluated in the following section. The arguments here are not made on the basis of criticism of recent judicial appointments in New Zealand but rather from the concern that future appointments may be at risk of improper political influence.

\section{Strength of the constitutional convention}

The first bulwark against political appointments is the convention that the Attorney-General, as senior law officer, makes appointments independently of party political considerations. ${ }^{57}$ The Attorney-General is "guardian of the public interest and exercises an independent function not shared by other ministers". ${ }^{58}$ This is reflected in the fact that appointments are announced, but not discussed or approved, in Cabinet.

McGrath contends that the strength of this convention is often underestimated and that holders of offices governed by conventional duties have a strong sense of obligation not to fail in those responsibilities. ${ }^{59}$ Then Solicitor-General Terence Arnold QC expressed similar sentiments, saying "[t]hese conventions are robust, essentially as a result of the scrupulous way in which they have been understood and observed by the relevant actors over many years". ${ }^{60}$ Although an Attorney-

55 McGrath, above n 26, at 316. But see Allan, above n 35, at 105, where it is suggested that senior judges may have an informal veto if they are dead set against someone.

56 McGrath, above n 26, at 316.

57 Ministry of Justice, above n 33, at [29].

58 Joseph, above n 27, at 67.

59 McGrath, above n 26, at 317. Also see Palmer, above n 8, at 44.

60 Arnold, above n 36, at 7. 
General could foreseeably breach this convention, McGrath offers the reminder that "this can be said of many of our offices that are restrained by constitutional conventions". ${ }^{61}$

While it is true that all conventions are by their very nature at risk of being ignored, the operation of some conventions permits significantly more public oversight than others. It would be widely known, for example, if the Governor-General breached convention by refusing to assent to legislation or by acting contrary to a Minister's advice and an appropriate response to the breach could accordingly be formulated. Conversely, there is much less scope for public confirmation or verification of the convention's strength in respect of judicial appointments. Only the AttorneyGeneral can know whether the appointment was driven by improper considerations.

The convention demanding independence in judicial appointments is therefore unlike other conventions that restrain the exercise of certain public offices as the public rely heavily on the integrity and assurances of "insiders" to assess its strength. Unsurprisingly, this provides a lesser sense of certainty about the reliability of the process. McCormick, speaking of the situation in Canada where a very similar appointments process was adopted, summarised the problem: ${ }^{62}$

It may well be that the right people are involved, that they are making their decisions on defensible criteria, and that their advice is strictly followed by the politicians, with purely professional considerations always being preemptive - but since we do not know that this is the case, we have to take

it on faith, and this phrase is the very antithesis of transparency.

The confirmation from several Attorneys-General and Solicitors-General that appointments occur independently of political considerations certainly increases confidence in the process. However, doubts are always likely to linger and perceptions of bias arise, regardless of how impartial appointments are in practice, simply by virtue of the fact that appointments are made by a government minister without public oversight. ${ }^{63}$ This sentiment is exacerbated in a society increasingly willing to question authority figures and demand greater transparency. ${ }^{64}$

\section{Political accountability}

In addition to the convention against political appointments, a second bulwark exists. As the Attorney-General is a minister, appointments can be subjected to the political accountability that corresponds with that office. This form of protection has two manifestations, both internal and

61 McGrath, above n 26, at 317.

62 McCormick, above n 19, at 24-25.

63 See Jeffrey Jowell "The Growing International Consensus in Favour of Independent Judicial Appointment Commissions" in Judicial Appointments: Balancing Independence, Accountability and Legitimacy (Judicial Appointments Commission, 2010) 1 at 3.

64 For discussion of this change in public attitudes, see for example Thomas Eichelbaum "The Inaugural Neil Williamson Memorial Lecture: Judicial Independence Revisited" (1997) 6 Canta LR 421 at 421. 
external. The internal component is that accountability to Parliament, and therefore the public, affects the conscience of the Attorney-General and "brings home to [him or her] ... the need to make appointments on merit". 65

The second, external manifestation is that the Attorney-General may be questioned and held to account for his or her choices, including through Select Committee examination. ${ }^{66}$ Allan drew on the 2004 appointments to the new Supreme Court to illustrate the efficacy of this form of protection. $\mathrm{He}$ contended that, notwithstanding the absence of legal limits, political limits constrained the Attorney-General's exercise of discretion when appointing members of the new Supreme Court and led to the decision to elevate the then four most senior members of the Court of Appeal bench. ${ }^{67}$

However, it is contended here that such political limitations are less effective under ordinary circumstances when a single judge is appointed. The initial elevations to the Supreme Court, where Allan suggests that political opposition and pressures were able to be mobilised, was a unique situation as the issue played out publicly. Conversely, as the appointments process typically operates with little transparency it would be difficult to mobilise political opposition if it was suspected that an ordinary appointment was made, or a candidate was rejected, on inappropriate grounds. Former Chief Justice Sir Thomas Eichelbaum reminds us that "[w]hat remain unknown and unseen are the cases where for politically influenced reasons, particular persons are not appointed". ${ }^{6}$ The protection afforded by political accountability is fairly weak given that appointments occur in the absence of open and transparent procedures.

The primary disadvantages of the present system of appointments are its lack of transparency and the fact that the Attorney-General exercises a wide degree of discretion, with little beyond his or her integrity to safeguard the apolitical nature of appointments. The next part examines Canada's experience after its Charter was adopted, to help assess whether New Zealand's present appointments system should be retained if a supreme law Bill of Rights is enacted.

\section{IS THE PRESENT SYSTEM SUITABLE? CANADA'S EXPERIENCE}

Canada provides a case study in how enacting a supreme law instrument affects judicial independence and judicial appointments. Canada did not address the collateral issue of judicial appointments when its Charter was enacted. Post-Charter, appointments came under far greater scrutiny and the existing appointments system was widely criticised, but lasting and substantial reform has not been forthcoming.

65 McGrath, above n 26, at 316

66 Palmer, above n 8, at 42.

67 Allan, above n 35, at 106-107.

68 Eichelbaum, above n 64, at 427. 


\section{A Why Canada?}

Because of its similarities with New Zealand and the fact that it moved from an instrument similar to NZBORA to the Charter, Canada is a useful case study. Like New Zealand, Canada was a colony that imported the common law and legal traditions of the United Kingdom with appeals to the Judicial Committee of the Privy Council ending in 1949. ${ }^{69}$ Unlike New Zealand, Canada's federal system of provinces and territories affects judicial appointments; there are both federal and provincial courts, with a hierarchy within each category and varied systems of appointment. This article focuses on appointments to the Supreme Court of Canada (SCC) because these appointments in particular came under increased scrutiny post-Charter and were substantially reformed as a result.

The precursor to the Charter was the 1960 Canadian Bill of Rights, an ordinary federal statute with the same status as NZBORA. It was perceived as ineffective because of courts' hesitance to use the law forcefully, ${ }^{70}$ so in 1982 the Charter, a comprehensive Bill of Rights with supreme law status, was enacted.

The Charter makes several concessions to parliamentary sovereignty. Like s 5 of NZBORA, s 1 of the Charter provides that the rights and freedoms are "subject only to such reasonable limits prescribed by law as can be demonstrably justified in a free and democratic society". The "Notwithstanding Clause" allows provincial and federal legislatures to approve the application of a law notwithstanding a judicial finding that it breaches the Charter, but is rarely used. ${ }^{71}$

At the time the Charter was enacted, SCC appointments occurred in a manner very similar to New Zealand's present system. Appointments were made by the Governor-General who was advised by the Prime Minister for appointment of the Chief Justice, and the Minister of Justice, likely with the Prime Minister's input, for other SCC appointments. ${ }^{72}$ Although appointments before 1970 were frequently based on political connections, ${ }^{73}$ a major change in focus meant that appointments since

69 See McCormick, above n 19, at 8-9 for further background on this reform.

70 Munroe Eagles and Sharon A Manna "Politics and Government" in Patrick James and Mark Kasoff (eds) Canadian Studies in the New Millennium (University of Toronto Press, Toronto, 2008) 65 at 91. Notably the Supreme Court did find one law "inoperable" due to breach of the Bill of Rights: see $R v$ Drybones [1970] SCR 282.

71 Janet Hiebert "New Constitutional Ideas: Can Parliamentary Models Resist Judicial Dominance When Interpreting Rights?" (2004) 82 Tex L Rev 1963 at 1967-1968. Also see James Allan Democracy in Decline: Steps in the Wrong Direction (McGill-Queen's University Press, Montreal, 2014) at 28-29.

72 Peter Hogg "Appointment of Justice Marshall Rothstein to the Supreme Court of Canada" (2006) 44 Osgoode Hall LJ 527 at 528.

73 See McCormick, above n 19, at 14; and R Blake Brown "The Supreme Court of Canada and Judicial Legitimacy: The Rise and Fall of Chief Justice Lyman Poore Duff" (2002) 47 McGill LJ 559 at 566. 
that time were driven predominantly by competence rather than patronage. ${ }^{74}$ Research reveals no reference to constitutional conventions governing the non-political nature of appointments, thus the protection of this value appears weaker than in New Zealand.

\section{B Public Perception}

This section outlines the public's response to the judiciary's ability to make policy-laden decisions, in particular highlighting several worrying cases where civil society groups attempted to lobby decision makers on appointments. This illustrates the additional pressure and scrutiny placed on the judicial appointments system in the post-Charter environment.

\section{Public opinion}

Public perceptions of the judiciary and judicial appointments have been affected by the Charter. A 2002 poll indicated that two thirds of the public supported popular election of SCC judges. ${ }^{75}$ Although research reveals no equivalent polling from before the Charter's adoption, this number is surprisingly high and was seen by Morton to reflect Canadians' increased awareness of judges' policy-making function. ${ }^{76}$ Another 2003 poll found that Canadians were concerned by the increased law-making function of judges, finding that 71 per cent of Canadians agreed that "it should be up to Parliament and provincial legislatures, not the courts, to make laws in Canada". ${ }^{77}$

\section{Lobbying}

Recognising the increased power of judges, many civil society groups have responded by seeking to influence judicial appointments. The National Action Committee on the Status of Women began in 1981 to lobby for the appointment of a woman "acceptable to [their] purposes" on the SCC. ${ }^{78}$ Their later "influencing the influencers" campaign aimed to influence judicial appointments and judges' ongoing professional education. ${ }^{79}$ A prominent judgment concerning abortion prompted a member of Choose Life Canada to say that her group would attempt to influence future

74 Lori Hausegger, Matthew Hennigar and Troy Riddell Canadian Courts: Law, Politics, and Process (Oxford University Press, Toronto, 2009) at 167.

75 Florian Sauvageau, David Schneiderman and David Taras The Last Word: Media Coverage of the Supreme Court of Canada (UBC Press, Vancouver, 2006) at 28.

76 FL Morton "Judicial Appointments in Post-Charter Canada: A System in Transition" in Kate Malleson and Peter H Russell (eds) Appointing Judges in an Age of Judicial Power: Critical Perspectives from around the World (University of Toronto Press, Toronto, 2006) 56 at 56.

77 Morton, above n 76, at 56.

78 Justice Committee "National Action Committee on the Status of Women Memo" (September 1981) at 5; and Justice Committee "National Action Committee on the Status of Women Memo" (March 1981) at 4, as cited in Morton, above n 76, at 60.

79 Morton, above n 76, at 61. 
appointments. ${ }^{80}$ The President of an opposing organisation responded that, while her group had never tried to influence appointments previously, it would if necessary in the future. ${ }^{81}$ The gay rights advocacy group ÉGALE lobbied members of the Government about a SCC appointment and, remarkably, members of the group even had a copy of the Government's shortlist of candidates. ${ }^{82}$

Whether or not these efforts succeeded, the problem is the perception that significant lobbying efforts have occurred and could influence the appointment. Williams points out that lobbying an individual decision maker is more likely to be successful than influencing, for example, an appointments commission. ${ }^{83}$ Concern about this kind of improper influence can have a delegitimising effect regardless of its impact on the ultimate decision.

Lobbying was not restricted to civil society groups; Canadian Members of Parliament (MPs) have similarly stated the importance of influencing appointments. James Jepson MP said that "[w]e now have a chance to put men and women on the bench with a more conservative point of view". 84 Although at the time his comments represented a "sharp break" from Canadian practice, in retrospect they are seen as "mark[ing] the beginning of a growing demand for greater transparency and public participation in Supreme Court appointments". ${ }^{85}$

\section{Reform of Judicial Appointments}

The SCC appointment system has undergone significant reform over the past decade. Although questions have been raised about the political neutrality of some appointments, concern about existing examples of patronage was not the main trigger for reform; instead it was the judiciary's increased power compared to the legislature and concern about the lack of transparency that drove reform. ${ }^{86}$ There seems to have been a genuine desire to involve Parliament in the process and enhance the democratic legitimacy of the Court. After the Prime Minister criticised the "democratic deficit" in Canada, due partly to the judicial appointments system, the House of Commons Justice Committee suggested as more transparent alternatives the creation of an appointments commission

80 "Public to demand say in Court Appointments" Lawyers Weekly (12 February 1988) at 1, as cited in Morton, above $\mathrm{n} 76$, at 61

81 "Public to demand say in Court Appointments" Lawyers Weekly (12 February 1988) at 1, as cited in Morton, above $\mathrm{n} 76$, at 61 .

82 FL Morton "To Bring Judicial Appointments Out of the Closet" Globe and Mail (Toronto, 22 September 1997, A15) in Morton, above n 11, at 154.

83 Williams, above n 25, at 62 .

84 Morton, above n 76, at 61.

85 Morton, above n 76, at 61.

86 See Gee, above n 23, at 109. 
and legislative scrutiny of prospective nominees ${ }^{87}$ Attempts to implement these recommendations are examined below.

\section{Early reforms}

In 2004 the Minister of Justice announced that two SCC nominees would be subject to parliamentary review. Despite lofty goals, the review was fairly innocuous: it occurred in a single session one day after the announcement, very few MPs were involved, the panel had no power to delay or veto the nomination and, most surprisingly, the panel questioned neither the candidates themselves nor the Prime Minister who selected them; instead, questions were directed to the Minister of Justice who stated explicitly that the appointment had not been his decision. ${ }^{88}$ One journalist likened this as akin to "sending your mother to do your job interview". 89

Given the disdain that had greeted the previous attempt to add greater transparency to the process, a new approach involving an Advisory Committee was announced in $2005 .{ }^{90}$ There were several problems, including that the Committee was dominated by politicians and federal appointees $^{91}$ and had a very narrow role cutting an eight-person shortlist provided by the Department of Justice to three persons. In-person interviews of candidates would not be permitted and the Committee could not add additional names to the initial eight. A decision would ultimately be made by the Prime Minister who could make an appointment from outside the shortlist if considered necessary. The Minister of Justice would appear before the Justice Committee to explain the process after each appointment.

After this Committee created its shortlist, the governing party lost an election. One of the policies of the newly elected Conservative Government was a public, parliamentary interview for proposed SCC appointees. ${ }^{92}$ Thus the new Government chose one name from the shortlist created by the former Government's Advisory Committee and had the nominee, Marshall Rothstein, appear before the Justice Committee.

87 Hausegger, Hennigar and Riddell, above n 74, at 169.

88 McCormick, above n 19, at 29.

89 Hausegger, Hennigar and Riddell, above n 74, at 169.

90 Ministry of Justice Proposal to Reform the Supreme Court of Canada Appointments Process (April 2005). This proposal is explained and critiqued by McCormick, above n 19, at 38-41.

91 The Committee was comprised of one member nominated by each political party recognised in the House of Commons, one retired judge, one member nominated by the Attorney-General of the relevant province for which the appointment is made, one member nominated by the law society of the relevant province and two lay members nominated by the Minister of Justice.

92 Hogg, above n 72, at 529. 


\section{Legislative hearings}

Over a three-hour televised session, Rothstein was questioned by 12 MPs representing the various political parties. A constitutional expert moderated the session and outlined the types of questions that were not appropriate, for example, the nominee's position on hypothetical cases or why he decided a particular case the way he did. ${ }^{93}$ The MPs were "extremely polite and deferential", some apologetic that he was even subjected to the review, and far less aggressive in their questioning than their American counterparts; while some MPs raised controversial topics like abortion, the Chair told the nominee that a response was not necessary. ${ }^{94}$ Committee members had no voting power but were invited to submit their views to the Prime Minister, who later formally announced Rothstein's appointment. ${ }^{95}$

This new process was controversial. Chief Justice Beverly McLachlin opposed the hearing, as did various former Presidents of the Canadian Bar Association and other prominent legal professionals. ${ }^{96}$

A different process again was adopted in 2008. A committee of five MPs - two from the Government caucus and one from each opposition party - would privately review a list of names put forward by the Government and produce a three-person shortlist. ${ }^{97}$ However, the Committee descended into partisan bickering and an election intervened before the nominee could appear, as intended, before a parliamentary committee. There was essentially a reversion to the original process and the Prime Minister simply announced the nomination of Thomas Cromwell following discussions with the Leader of the Opposition. ${ }^{98}$

After this episode, some consistency in the process was achieved. ${ }^{99}$ Several subsequent appointments were made where a committee of MPs reviewed a list of candidates to form a shortlist from which the Prime Minister and Minister of Justice selected the final candidate. The composition of these committees was however odd: only MPs were involved and in each case a majority of members were from the governing party. A legislative hearing with the chosen candidate then took place.

93 Hogg, above n 72, at 538.

94 Hausegger, Hennigar and Riddell, above n 74, at 142.

95 Hogg, above n 72, at 530.

96 Jacob Ziegel "A New Era in the Selection of Supreme Court Judges" (2006) 44 Osgoode Hall LJ 547 at 548.

97 Department of Justice of Canada "Minister of Justice Announces Selection Process for the Supreme Court of Canada" (press release, 28 May 2008).

98 Adam Dodek "Reforming the Supreme Court Appointment Process, 2004-2014: A Ten Year Democratic Audit" (Ottawa Faculty of Law Working Paper No. 2014-07, University of Ottawa, Ottawa, 2013) at 15.

99 See Dodek, above n 98, at 14-17. 
After several years of consistency, appointments returned to a state of flux in 2013 following the appointment of Marc Nadon. After being sworn in as a SCC Judge, his appointment was nullified by the Supreme Court as he was deemed ineligible based on legislation requiring that three SCC Judges be from Quebec. ${ }^{100}$ Further problems arose because the shortlist created by the committee of MPs was subsequently leaked to the media. ${ }^{101}$ The appointment of Clément Gascon was simply announced by the Prime Minister. This reversion to the original appointments process allegedly occurred because the Government "no longer trusted" the reformed appointments system. ${ }^{102}$ Similarly, the most recent appointment of Suzanne Côté did not involve a legislative hearing. ${ }^{103}$ It is unclear what process will be adopted in future but appears the present Government no longer has confidence in the new process it implemented.

\section{REFORMING APPOINTMENTS IN NEW ZEALAND}

Canada's experience - enacting the Charter while initially retaining a judicial appointments system similar to New Zealand's - offers several insights of relevance to New Zealand. It suggests that reform of New Zealand's appointments system would be necessary and indicates how that reform should proceed.

\section{A Reform is Needed}

Canada's experience shows that enacting a supreme law Bill of Rights is likely to expose New Zealand's judicial appointments system to far greater scrutiny and it seems unlikely to be able to withstand the additional pressure inevitably placed upon it. Canada enacted a supreme law instrument but did not concurrently address the collateral consequences of this reform; it "never really worked through the implications of wedding ... an American-style interventionist court with a traditionally English style of appointing judges". ${ }^{104}$

The principal disadvantage of the previous Canadian approach was the wide discretion exercised by members of the government through a secretive process and without public oversight, where their integrity was the main safeguard of political neutrality in appointments. The ease with which

100 In the Matter of a Reference by the Governor in Council concerning sections 5 and 6 of the Supreme Court Act, R.S.C. 1985, c. S-26, as set out in Order in Council P.C. 2013-1105 dated October 22, 2013 [2014] 1 SCR 433.

101 See Sean Fine "The secret short list that provoked the rift between Chief Justice and PMO" Globe and Mail (online ed, Toronto, 23 May 2013).

102 Sean Fine "Legal observers worry future judicial appointments will be done in secret" Globe and Mail (online ed, Toronto, 18 September 2014). Also see Kim Mackrael and Sean Fine "Tories changed tack on Supreme Court appointments after Globe report" Globe and Mail (online ed, Toronto, 16 September 2014).

103 Sean Fine "PM picks Quebec lawyer Suzanne Côté for Supreme Court seat" Globe and Mail (online ed, Toronto, 27 November 2014)

104 McCormick, above n 19, at 17, referring to Morton, above n 76. 
the system could be criticised meant that, following high-profile Charter cases, the media and politicians increasingly questioned how appointments were made. ${ }^{105}$ Judicial appointments also became a prominent political issue; parties campaigned on policies regarding judicial appointments and a sub-theme of the 2004 federal general election campaign was a concern about the kind of judicial appointments that a new conservative Prime Minister might make. ${ }^{106}$ The system's fragility was exposed and over time, almost every major Canadian newspaper noted the growing political influence of Canada's judges and criticised the nature of their appointment. ${ }^{107}$

Canada's experience suggests that if New Zealand enacts a supreme law Bill of Rights, the judicial appointments system will similarly be subject to significantly more scrutiny. It has not been immune to criticism even in the absence of a supreme law Bill of Rights; a former Chief Justice, former President of the Court of Appeal and former Attorney-General have, among others, called for reform. ${ }^{108}$ As occurred in Canada, these calls are only likely to grow louder and more widespread once judges have the power to strike down legislation.

New Zealand's present appointments process shares the same fundamental weaknesses as the previous Canadian system. The non-political nature of appointments is predominantly safeguarded by the integrity of a member of the executive rather than by formal checks and balances. Too much power is concentrated in the hands of one individual, especially since the power to shape the courts' composition would be more potent than ever if judges were capable of striking down legislation. The appointments process lacks transparency and is closed and exclusive; it "makes no effort to elicit the support for the appointments of members of the legislature, whose laws the appointee will eventually review". ${ }^{109}$ Thus the present system of appointments is insufficiently robust to withstand the scrutiny that will inevitably be placed upon it should a supreme law Bill of Rights be enacted. Reform of the process should occur.

\section{B Character of the Necessary Reform}

This consideration of the Canadian experience offers four broad conclusions about the process that should be adopted in reforming judicial appointments: reform should be proactive, codified, nonpartisan and responsive.

105 See for example Sauvageau, Schneiderman and Taras, above n 75, at 159-160, which considers the widespread coverage of the Supreme Court's decision in $R v$ Marshall, including criticism of judicial appointments and calls for a more transparent system. Also see Jacob Ziegel "Merit, Selection and Democratization of Appointments to the Supreme Court of Canada" in Morton, above n 11, at 159.

106 McCormick, above n 19, at 27. For example the Conservative Party campaigned on a policy of public parliamentary interviews for proposed SCC appointees.

107 Hausegger, Hennigar and Riddell, above n 74, at 141

108 See Eichelbaum, above n 64; Cooke, above n 22; and Wilson, above n 36.

109 Jowell, above n 63, at 3. 


\section{Proactive}

First, reform of judicial appointments should be proactive in that New Zealand should consider changing how judges are appointed prior to or alongside a decision to enact a supreme law Bill of Rights. There is a contrary argument that a supreme law Bill of Rights should be enacted without addressing collateral issues like judicial appointments. On this view, it is unnecessary to pre-empt the effects of such reform and prematurely respond to problems that may not eventuate.

Canada's experience shows why this argument - the "if it ain't broke, don't fix it" approach to law reform - is problematic. Despite recognition of the need for improvement, in Canada there has been little agreement on the appropriate reform. The appointments models adopted since 2004 have varied widely: some appointments have involved a screening or appointments commission (of differing compositions, most recently made solely of MPs, the majority of which were from the governing party), others have included legislative hearings and others have been made by reverting to the previous system. ${ }^{110}$

Why has achieving lasting change been so difficult in Canada? Commentators see the government's vested interest in retaining control over appointments as a major inhibitor to substantive reform. The government's main concern, it is suggested, is with superficial appearances rather than genuine improvement. ${ }^{111}$

Failing to address wider issues like judicial appointments before enacting a supreme law Bill of Rights risks creating a political environment in which achieving genuine reform becomes increasingly difficult. To avoid this, proactive reform which addresses collateral issues like judicial appointments alongside the decision to adopt a supreme law Bill of Rights is desirable. A similar argument is often advanced in favour of enacting a supreme law Bill of Rights itself; even in the absence of rights infringements in the past "[i]t is much better not to wait for a flood before we build the dam. The planning and building should take account of the threat by careful thought and execution in advance."112 Furthermore, Paul East suggested that a judicial appointments commission, once created, would be politically impossible to disband. ${ }^{113}$ This scenario illustrates the desirability of a measured approach to reform over a knee-jerk response to sudden pressures placed on the system.

110 Dodek, above n 98, at 14-17.

111 McCormick, above n 19, at 42 .

112 Palmer, above $\mathrm{n} 4$, at [4.24].

113 East, above n 36, at 190. 


\section{Codified}

The second conclusion is that reform should be codified. The changes in Canada were not and instead the process to be adopted was simply announced by the Minister of Justice when a vacancy arose. ${ }^{114}$ The series of fluctuating and inconsistent methods of appointment adopted in Canada undermine the aims of increasing transparency and public confidence in appointments, thus codification of changes is a desirable way of ensuring greater consistency in the way judges are appointed.

\section{Nonpartisan}

Thirdly, any reform should be nonpartisan. That was not the case in Canada; as outlined above, the varying systems of appointment have taken place under two governments and the method of appointing judges became a political issue. Appointments are presently in a state of flux and it is not clear what system a new government would adopt, given the inconsistencies in approach adopted by the present Government. This is a worrying state of affairs for an issue of constitutional significance. A nonpartisan approach to reform would go some way towards insulating appointments from political attacks and ensuring consistency in the method of appointment.

\section{Responsive}

The fourth conclusion is that reform of appointments must respond to the problem. Canada failed to precisely define the present problem and respond substantively to it and consequently, the value of its reforms is undermined.

The legislative hearing process in Canada did little to limit the Prime Minister's exercise of discretion. While the Prime Minister contended that the hearing process "brought unprecedented openness and accountability to the process", ${ }^{115}$ this is an overstatement considering that many questions were off limits and the hearings did not offer reasons why one candidate was chosen over another qualified individual. Furthermore, many of the questions asked at the various hearings were inane and gave MPs little information of value in determining whether the appointee was qualified. ${ }^{116}$ The MPs had no voting power and the nomination could have proceeded even if they had expressed disapproval of the nominee. Therefore the reform appears to be little more than

114 See for example Department of Justice of Canada "Minister of Justice Announces Selection Process for the Supreme Court of Canada" (press release, 28 May 2008).

115 Prime Minister's Office "Prime Minister announces appointment of Mr. Justice Marshall Rothstein to the Supreme Court" (press release, 1 March 2006).

116 Transcripts from the more recent hearings are available on the Ministry of Justice website, <canada.justice.gc.ca>. Also see Peter Hogg "Appointment of Thomas A Cromwell to the Supreme Court of Canada" (2009) 47 SCLR 413 at 426. 
rubber stamping of nominees; it creates a public process but does not truly create a check on the Prime Minister's exercise of discretion.

The more recent involvement of a committee of Canadian MPs is also of questionable value. The composition of these committees gave the governing party's MPs a majority, and non-political actors like judges or law society representatives were excluded. The dominance of government MPs, and the absence of independent non-political actors, means that the committee cannot be considered an impartial body independent of government.

Thus the problem with this reform is that it does not act as an effective and independent check on the Prime Minister's exercise of discretion. The value of the legislative hearing was instead to allow MPs and the public to get to know the appointee and to hear their views on, for example, their role as judges or their understanding of Charter rights. The hearing, Hogg contended, sent a reassuring message about the nominee's abilities and integrity. ${ }^{117} \mathrm{He}$ also saw the hearing as a useful antidote to charges of judicial activism that frequently arise following unpopular decisions. ${ }^{118}$

While these are undoubtedly positive consequences, they do not address one of the main problems with the present system: the lack of checks on the executive's responsibility for judicial appointments. There was a failure to define the precise nature of the problem and respond accordingly, meaning the reforms enacted in Canada are more superficial than substantive. Therefore the next section attempts to define the present problem, creating a framework within which possible reforms can be assessed.

\section{$C$ The Purpose of Reform}

To enact responsive and lasting reform, it is necessary to identify precisely what it aims to achieve. McGrath summarised the goals of an appointments system as protecting political neutrality, adherence to merit based criteria, maintaining public confidence in the judiciary and accountability for appointments. ${ }^{119}$

The first value identified - political neutrality - is of central importance in a system with a supreme law Bill of Rights. It comprises twin goals: to enhance the political neutrality of appointments and prevent the government from being able to stack a court, and to quell the perception that ideological appointments could occur. Even if appointments are politically neutral in fact, unless they are perceived to be so the door is open to political sensations and attacks in response to appointments or following unpopular judgments. As discussed above, part of a Canadian federal election campaign concerned the sorts of conservative judicial appointments that a new

117 Hogg, above n 72, at 534.

118 Hogg, above n 72, at 534 .

119 McGrath, above n 26, at 317. 
government might make. ${ }^{120}$ These sorts of attacks have a corrosive effect on public confidence in the judiciary's independence and the appointments system should aim to reduce the risk that they would occur.

Secondly, McGrath emphasises adherence to merit-based criteria. Undoubtedly, appointments must be based on merit but this does not mean legal ability alone. The appointments system should also foster the appointment of individuals with empathy and encourage diversity of experience among appointees as these characteristics, while important in any group of judges, are of heightened importance when judges have the ability to strike down laws. Jeffrey Jowell suggests that "qualities such as social sensitivity or political sagacity" are needed if a supreme law Bill of Rights is enacted. ${ }^{121}$ Similarly, to Canadian Chief Justice Beverly McLachlin, it is particularly important that judges possess the following qualities in the post-Charter environment: ${ }^{122}$

...they must remain in touch with the world about them if they are to render relevant and helpful decisions. It is also obvious that the composition of the courts should reflect insofar as possible the broad mosaic of our society, the better to guard against the predominance of uniform insularity.

McGrath also notes that public confidence in the judiciary must be protected. In addition to maintaining confidence in the judiciary's independence, the appointments system should also foster the democratic legitimacy of judges to avoid the perception of a democratic deficit, a concern that arose in Canada. ${ }^{123}$ The reduction in Parliament's law-making authority and the transfer of power to the courts may be perceived as undemocratic, heightening the importance of democratic legitimacy in a supreme law Bill of Rights environment.

Accountability for appointments is the fourth value and is linked to the point on public confidence. If judicial appointments are made without sufficient input from elected representatives, weakening the sense of accountability to the public, the judiciary risks being perceived as elitist and unqualified to assess the policy and political considerations that may inform a decision to strike down legislation. Other factors include protecting confidentiality to avoid deterring possible candidates from seeking judicial office; avoiding unnecessary expense or administrative burdens; and accordance with New Zealand's common law tradition and political culture.

While a key goal of reform is to create a system where judicial appointments are perceived to be, and are in fact, free from the sorts of improperly political considerations identified above, this cannot be the sole focus at the expense of the other values identified. The following parts explore various options for reform and assess their performance against the aforementioned criteria.

120 McCormick, above n 19, at 27.

121 Jowell, above n 63, at 3.

122 McLachlin, above n 12, at 543

123 See McCormick, above n 19, at 2. 


\section{OPTIONS FOR REFORM}

\section{A The Judicature Modernisation Bill}

The Judicature Modernisation Bill arose following a Law Commission report. The Commission endorsed the status quo appointments system with recommendations designed to increase its transparency and ensure consistency in its application. ${ }^{124}$ Several of these recommendations were not included in the subsequent Judicature Modernisation Bill but with little explanation for their omission. It is suggested here that the Commission's recommendations are valuable but insufficient alone to respond to the issues raised in this article.

One recommendation that was accepted by the Government would require the Attorney-General to publish the process he or she would follow in soliciting and advancing nominations for judicial appointment. ${ }^{125}$ A second would codify the requirement that the Attorney-General consult various individuals, including senior judges, the Solicitor-General and the Presidents of the Law Society and Bar Association, before making appointments or elevations to the higher courts. ${ }^{126}$ The inclusion of elevations in this recommendation accorded with the view of many submitters to the Commission who saw the consultation process as being of equal, if not greater, importance for judicial elevations as for the initial appointment. ${ }^{127}$ The Commission was of the view that this would not create an undue administrative burden on those involved as relatively few appellate appointments are made each year. ${ }^{128}$

It is appropriate that the Commission considered elevations to be equally as important as initial appointments. Elevations to higher courts are particularly significant and likely to attract the most attention if a supreme law Bill of Rights were enacted, given that decisions striking down legislation are likely to be appealed to the Supreme Court.

In addition, while recognising that no single template is achievable or desirable for New Zealand judges, the Commission also suggested some general principles that an Attorney-General ought to observe in making appointments ${ }^{129}$ and recommended that criteria for appointment be included in statute. $^{130}$

124 Law Commission, above n 47, at recommendations 12-17.

125 Law Commission, above n 47, at recommendation 15. See the Judicature Modernisation Bill 2013 (178-2), cl 93.

126 At recommendation 17 .

127 At [5.26]-[5.27]. Submitters of this view included the New Zealand Law Society, the New Zealand Bar Association, the Chief District Court Judge and the senior courts' Judges.

128 At [5.28].

129 At [5.43].

130 At recommendation 16. 
The Ministry of Justice, in a document explaining the Judicature Modernisation Bill's changes to judicial appointments, accepted that "scope exists to achieve greater clarity and transparency in the judicial appointment process, given the limited publicly available information". ${ }^{131}$ Despite this recognition, the Bill is significantly less comprehensive than the Commission recommended. The Bill codifies neither the requirement for consultation with specified individuals nor criteria for appointment; instead cl 93 sets out a requirement for the publication of information concerning the appointments process: $:^{132}$

\section{Attorney-General to publish information concerning judicial appointment process}

The Attorney-General must publish information explaining his or her process for-

(a) seeking expressions of interest for the appointment of Judges and Associate Judges; and

(b) recommending persons for appointment as a Judge or an Associate Judge.

While cl 93 improves the present system, it falls short of what the Commission proposed with little discussion of or explanation for the omissions. A response to the Commission's report from the Minister of Justice suggested that a desire to retain flexibility led to the view that criteria for appointment should not be codified. ${ }^{133}$ Although this approach accords with the view of some submitters, ${ }^{134}$ the majority agreed that there should be statutory criteria, ${ }^{135}$ and submitters almost unanimously agreed with the other significant proposal - that consultation with specified individuals should be mandatory and formalised in legislation. ${ }^{136}$ It is unfortunate that the Commission's measured reforms, which would enhance the transparency of the appointments process and ensure greater consistency in its application, were largely rejected without sufficient explanation.

The Commission's report offers welcome improvements and is an appropriate response to current concerns about judicial appointments, but it is not sufficient to address the issues raised in this article because the Attorney-General would retain wide discretion over appointments. The subdued nature of the recommendations was recognised by the Commission; its focus was "a

131 Office of the Minister of Justice, Cabinet Social Policy Committee Government response to the Law Commission's Report: Review of the Judicature Act 1908: Towards a New Courts Act (Ministry of Justice, Wellington, April 2013) at [31].

132 Judicature Modernisation Bill 2013 (178-2), cl 93.

133 Office of the Minister of Justice, above n 131, at [31]-[32].

134 Law Commission, above n 47, at [5.42].

135 At [5.43].

136 At [5.54]-[5.55]. 
modest consolidation project". ${ }^{137}$ Therefore, it is necessary to go beyond the Judicature Modernisation Bill to seek more comprehensive options for reform.

\section{$B$ Election and Formal Training}

Although some jurisdictions elect judges, this undermines the independence of the judiciary and with it the rule of law. Election is unlikely to be favoured in New Zealand and can be dismissed as a feasible or desirable possibility. Friedland, although writing in the Canadian context, summarised the case against electing judges: ${ }^{138}$

Few things would be more destructive of the independence of the judiciary than to have judges campaign for office accepting contributions to pay for their campaigns, let alone having to run on a lawand-order platform.

Similarly, the civil law model where judges are formally trained in a separate career path to lawyers is not considered here because New Zealand's common law tradition, where most judges have had at least 15 years of experience in legal practice, is very likely to be retained in the future. Any reform must conform to this tradition.

\section{Public Legislative Hearings}

Legislative hearings at which nominees are questioned by elected representatives take place in Canada and the United States. Under this reform, the present system of appointment would be retained but a candidate selected by the Attorney-General would appear before a committee of MPs prior to being officially appointed by the Governor-General. The varying forms that legislative hearings could take are discussed below but ultimately it is contended that public hearings are not a desirable reform.

The American model for Supreme Court confirmation hearings should not be adopted in New Zealand. Given that the hearings are conducted publicly and Senators can block a Supreme Court nominee, the hearings are characterised by aggressive questioning and politicking. ${ }^{139}$

An alternative is the Canadian model where MPs question appointees at a public hearing but cannot vote. The absence of voting "lowers the temperature" of the hearing and purportedly makes the occasion less political. ${ }^{140}$ However, the process also comes across as superficial rather than as a real check on the decision maker because the government can insist on its nominee regardless of the hearing's outcome. As MPs could not vote to show their opposition to a candidate, they may

137 At [5.32].

138 Friedland, above n 19, at 58.

139 Hausegger, Hennigar and Riddell, above n 74, at 142.

140 Hogg, above n 72, at 532. 
publicly express their concerns which would be damaging to the candidate if they were nevertheless appointed to the bench.

Furthermore, the absence of voting is not a guarantee that MPs would conduct themselves in an appropriate manner. Although the first Canadian hearing was polite, in 2011 SCC appointee Michael Moldaver was subjected to "glib and disrespectful challenges" concerning his inability to speak French; he was asked over five times about this issue and was asked one question in French, an approach surely meant only to embarrass him. ${ }^{141}$ The presence of a Canadian constitutional expert moderating the session did not prevent these sorts of attacks. Unfortunately, New Zealand's political culture means that MPs would be likely to behave similarly and undermine the value of the process, using it as an opportunity to score political points. Therefore, public legislative hearings in either the American or Canadian model should not be adopted in New Zealand.

\section{PRIVATE CONFIRMATION}

Given the problems associated with public hearings, an alternative reform would create a private process through which an individual or group confirms the suitability of the appointment. Under this model, the Attorney-General could nominate an individual for judicial appointment with the same consultative process presently adopted, but the nominee would only be appointed if their appointment was confirmed by the specified individual or group. A rejection would require the Attorney-General to submit a new candidate.

Approval of the Attorney-General's nomination could come either from a judge, a group of MPs or a specifically constituted committee. The Law Commission raised the possibility that the concurrence of the Chief Justice or relevant Head of Bench could be required, creating a judicial veto over appointments. ${ }^{142}$ The problem with this approach is two-fold; it risks self-perpetuation within the judiciary ${ }^{143}$ and does too little to enhance the transparency and democratic legitimacy of the process.

An alternative would require the nominee to appear before a private confirmation hearing conducted by MPs - likely the Justice and Electoral Select Committee. The absence of public exposure would reduce the incentive for politicking, permitting a more productive session than the previously discussed public hearings. However, if the governing party and its partners held a majority on the Select Committee, the process may lack the necessary rigour to create a real check sufficient to stop political opponents from publicly criticising appointments. A group of MPs may

141 Emmett Macfarlane "Why public hearings with Supreme Court nominees should mean something" (20 October 2011) Macleans <www.macleans.ca>.

142 Law Commission, above n 47, at [5.33].

143 See McGrath, above n 26, at 316, who suggested that the Attorney-General having discretion over appointments, in the absence of a judicial veto, has encouraged the appointment of lawyers with less orthodox backgrounds to the bench. 
also give weight to peripheral considerations rather than the candidate's legal ability and suitability for appointment. For example, Justice Rothstein derived support from Canadian MPs for being "very 'judge-like"" 144 and for "his informality, self-deprecating sense of humour, and willingness to explain his judicial philosophy in simple terms". ${ }^{145}$ The involvement of a number of MPs also increases the risk that information would be leaked to the media if politically expedient, particularly if a minority of the committee members were opposed to the nominee, potentially deterring good candidates from seeking judicial office.

A third option is the creation of a specifically constituted committee responsible for approving the Attorney-General's decision. This committee would be likely to include the Chief Justice and Solicitor-General, as representatives of the bench and bar, and could include lay members and MPs.

Retaining the Attorney-General as the primary decision maker will be seen by proponents of this model as its main advantage. Ministerial responsibility is not diluted so the conventions that presently govern appointments can continue to operate, but with a genuine check on the AttorneyGeneral's exercise of discretion. The committee could also provide feedback to the AttorneyGeneral if it were concerned about, for example, the homogeneity of appointments. The committee's voting power and ability to reject a candidate means that it cannot be dismissed as a mere process of rubber stamping.

However, the central role of the Attorney-General is also this proposal's main weakness. One of the main problems with the present system is the concentration of decision-making power in one person. It is hard to justify why one individual, even a government minister, should have this level of influence over the judiciary's composition in a system where judges' powers would be substantially wider than at present. This reform does too little to change that. Because the committee cannot propose individuals for appointment, but can solely approve or reject the Attorney-General's nomination, its influence is fairly limited and does not provide a sufficient counter-balance to the government's influence over the process.

\section{APPOINTMENTS COMMISSION}

An appointments commission is a prominent option for reform; commissions have been adopted with increased frequency overseas including in the United Kingdom, ${ }^{146}$ and commissions have been proposed in New Zealand in $1978^{147}$ and again in the 1990s, with the idea attracting support from

144 Hausegger, Hennigar and Riddell, above n 74, at 143.

145 Ziegel, above n 96, at 549. Also see Hogg, above n 116, at 426.

146 Jowell, above n 63, argues that there is a growing global consensus in favour of the use of judicial appointments commissions.

147 See "Report of the Royal Commission on the Courts" [1978] VII AJHR H2 at 200-202. The proposed commission would have comprised the Chief Justice, the Chief District Court Judge, the Solicitor-General, the Secretary for Justice and two New Zealand Law Society nominees. 
Cooke P and Eichelbaum CJ. ${ }^{148}$ The issue arose again in 2004 when many submissions on the legislation creating the Supreme Court expressed distrust of the existing system and supported the formation of a judicial appointments commission. ${ }^{149}$ The Ministry of Justice produced a consultation paper ${ }^{150}$ but the idea was not pursued, although then Attorney-General Margaret Wilson still supports the creation of an independent body to recommend appointments. ${ }^{151}$

\section{A Appointing or Recommending Commission}

There are broadly two models for an appointments commission. The first has total responsibility for the appointment, whereas the second, which is more common overseas, operates as a recommending commission which produces a shortlist from which the Attorney-General makes the final selection. ${ }^{152}$

The primary disadvantage of the first model is the reduction in accountability to Parliament. Former Chief Justice of Australia, Sir Anthony Mason, suggested that: ${ }^{153}$

... there is a powerful democratic argument against transferring the power of appointment away from the executive government to a commission consisting of persons who are not elected by the people. One justification for the exercise of judicial power by non-elected Judges in a democracy is that the Judges are indirectly appointed by the people in that it is the duly elected government that makes the appointments. That is a very important argument which tells against entrusting the power of appointment to others, whatever the advantages may be in pursuing such a course.

Although arguing against an appointments commission, Mason's statement suggests that involving the Attorney-General in some capacity is essential to avoid an undesirable reduction in democratic legitimacy. This is particularly important given the heightened need to protect the democratic legitimacy of judges operating under a supreme law Bill of Rights. The concern in the United Kingdom, which could apply equally in New Zealand, was that by removing the Lord Chancellor from appointments, he or she would "cease to operate so effectively as a bridge between the judiciary and Government". ${ }^{154}$ Removing the Attorney-General from the process may also make

148 Joseph, above n 18, at [21.4.1(3)]. See also Cooke, above n 22, at 1331; and Eichelbaum, above n 64, at 427-429.

149 Ministry of Justice, above n 33, at [16]. See also Joseph, above n 27, at 70.

150 Ministry of Justice, above n 33.

151 Wilson, above n 36, at 48.

152 Straw, above n 24, at 57.

153 Anthony Mason "The Appointment and Removal of Judges" in Helen Cunnningham (ed) Fragile Bastion (Judicial Commission of New South Wales, Sydney, 1997) 1 at 16-17.

154 Ministry of Justice The Governance of Britain: Judicial Appointments (October 2007) at [4.15]. 
him or her less inclined to defend the judiciary against criticism. ${ }^{155}$ A tension exists between creating a body which is independent of government while still ensuring accountability to Parliament and a commission with total responsibility for appointments errs too far to one extreme at the expense of accountability.

Another benefit to the recommending commission compared with the former model concerns the quality of candidates appointed for judicial office. Critics of an appointments commission express concern that it will encourage the appointment of conventional, compromise candidates, ${ }^{156}$ suggesting that the Attorney-General is well-placed to choose candidates with unorthodox backgrounds because he or she sees the courts in their wider social and political context. ${ }^{157}$ Tasking the commission with the creation of a shortlist, rather than recommending a single name, goes some way to mitigating this concern by ensuring greater scope for the commission to select individuals other than the most obvious and conventional candidates.

One contentious matter is whether the Attorney-General should be bound to accept the commission's shortlist. Eichelbaum CJ suggested that the Attorney-General should be free to make an appointment from outside the commission's shortlist, but that this would need to be publicly notified. ${ }^{158}$ However, this approach somewhat undermines the value of the reform given that the predominant concern with the present system is that there are too few formal checks on the Attorney-General. It is instead preferable to require the Attorney-General to select a candidate from the commission's shortlist, but he or she should be able to ask the commission to reevaluate its recommendation on clearly specified grounds and with reasons provided. ${ }^{159}$ A shortlist of three names would be appropriate; fewer places too significant a limit on the Attorney-General while more than three names risks undermining the value of the commission as a check on the decision maker.

\section{B Composition}

A commission's composition and how its members are appointed are highly contentious due to the risks that appointments to the commission may themselves become politicised and that the commission will be unduly dominated by judges, potentially leading to self-replication within the

155 At [4.15].

156 See Robert Stevens The English Judges: Their Role in the Changing Constitution (Hart, Oxford, 2002) at 144; and Allan, above n 35, at 110.

157 Palmer, above $\mathrm{n} 8$, at 83. Also see the discussion of this issue in Straw, above $\mathrm{n} 24$, at 75 .

158 Eichelbaum, above n 64, at 429.

159 See Kate Malleson "Creating a Judicial Appointments Commission: Which Model Works Best" [2004] Public Law 102 at 113 for a further discussion of this matter. 
judiciary. The following discussion explains these concerns and contends that the proposed commission's composition can alleviate them.

\section{Political appointments to the commission}

Critics suggest that appointments to a commission are at risk of being politicised as the political element could simply shift and operate in a more covert manner, where members of the government attempt to stack the commission to ensure their preferred candidates are selected. ${ }^{160}$ This situation appears to have occurred in Canada, where the Federal Government added a police representative to some federal commissions, seen as an attempt to ensure the appointment of "tough on crime" judges, and restricted the judicial representative from voting except in cases of a tie. ${ }^{161}$ This gave the Government the power to appoint a majority of the voting members of the commission and was heavily criticised, illustrating the need for a nonpartisan approach to reform to avoid as much as possible later alterations to the commission's composition. ${ }^{162}$

The appointments commission for England and Wales addresses this concern but in an administratively burdensome way. Their 15-person commission is comprised of lay people, lawyers, judges and lay judges. ${ }^{163}$ The three most senior judicial members are appointed by the Judges' Council while other commissioners are appointed by the Lord Chancellor after consultation with an advisory body comprising the Lord Chief Justice, the chair of the Commission and an additional lay member appointed by the Minister. ${ }^{164}$ Essentially, there is a separate advisory committee whose responsibility is appointing members of the appointments commission. This is a cumbersome process and its high administrative burden is exacerbated by New Zealand's small size and comparatively limited resources.

A preferable solution is for individuals to sit on the commission by virtue of another office they hold. Rather than making specific appointments to the commission, the Solicitor-General for example would automatically become a member by virtue of being Solicitor-General. The Ministry of Justice's 2004 Consultation Paper suggested the following composition: ${ }^{165}$

160 Palmer, above n 8, at 82; and East, above n 36, at 190.

161 Friedland, above n 19, at 55.

162 Friedland, above n 19, at 55-56. For example, the Canadian Judicial Council said that the reform "puts in peril the concept of an independent body that advises the government on who is best qualified to be a judge".

163 Constitutional Reform Act 2005 (UK), sch 12.

164 Sophie Turenne "Judicial Independence in England and Wales" in Anja Seibert-Fohr (ed) Judicial Independence in Transition (Springer, Heidelberg, 2012) 147 at 158-159.

165 Ministry of Justice, above n 33, at [78]-[79]. 
- three lay people, who are not practising lawyers and have never held judicial office, appointed by the Government;

- the Chief Justice (or nominee, who is a judge);

- $\quad$ one other senior judge (e.g. the Chief Judge of the Court in which the vacancy occurs);

- the President of the New Zealand Law Society (or nominee);

- the President of the New Zealand Bar Association (or nominee); and

- $\quad$ one of the following persons: 166

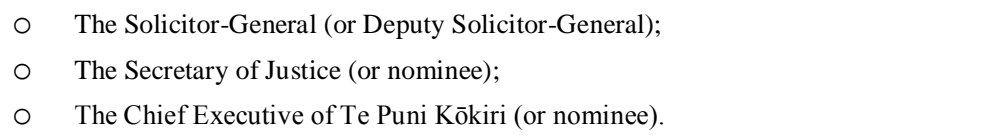

Most of these individuals would sit on the appointments commission by virtue of another role, circumventing the difficulties that arise when deciding which individuals, for example which judges or bar representatives, should be included. However, problems with this approach arise in respect of lay members.

Given the aforementioned concerns about the government appointing members of the commission, it is not desirable for the government to appoint three lay members as proposed in the 2004 Consultation Paper. One solution would be for lay members to also be appointed by virtue of an office they hold; for example, the Auditor-General or an Ombudsman could be members of the commission. It is suggested here that a better solution is for no lay members to sit on the commission.

Many appointments commissions include a number of lay members, with some comprised of a majority of lay members while other are chaired by a lay member. ${ }^{167}$ The argument for including lay members is that they bring fresh ideas and perspectives to the commission to balance the influence of judges who may otherwise dominate its decisions and encourage self-replication within the judiciary. ${ }^{168}$ There is some disagreement however about whether lay members can in fact balance the influence of judicial representatives. Palmer, for example, expressed concern that judges

166 The Consultation Paper proposed that the individual involved would depend on whether the appointment was to the superior courts (Solicitor-General); the District Court, including the Family and Youth Courts and the Employment and Environment Courts (Secretary of Justice); or the Māori Land Court (Chief Executive of Te Puni Kōkiri).

167 See Malleson, above n 21, at 48.

168 At 48 . 
who sat on the commission would exert great influence over lay members, suggesting this risks "turn[ing] the judiciary into a self-perpetuating oligarchy". ${ }^{169}$

A better mechanism for balancing the influence of judicial representatives is the inclusion of representatives from the bar, like the Solicitor-General and Presidents of the Bar Association and Law Society. As legally trained representatives of the bar they are well-positioned to assess the legal ability of candidates whereas lay members may be more likely to defer to judicial representatives on these matters.

\section{Members of Parliament}

Members of Parliament should sit on the commission, as occurs in several countries including South Africa and Israel. ${ }^{170}$ As the central democratic authority, Parliament has a valid interest in judicial appointments, particularly when judges have the ability to strike down legislation. Malleson contends that including MPs on a commission increases democratic accountability and hence the legitimacy of the process. ${ }^{171}$ Moreover, Canada's experience showed a very strong desire for MPs to be involved in appointments post-Charter with a number of reforms trying to accommodate this. If legislative hearings are not implemented in New Zealand - and there are good policy reasons why they should not be - another mechanism should be established for involving MPs in the process.

Shutting MPs out of the appointments process also runs counter to the goal of limiting political eruptions or sensations in response to appointments and unpopular judgments. Without their inclusion, the commission is at risk of being viewed as too insular and representative of the legal establishment. Thus by increasing the democratic legitimacy of the judiciary and reducing the likelihood of politicised attacks on judicial appointments, there are reasons of both principle and pragmatism for including MPs on the commission. Furthermore, the view that the commission should not include lay members strengthens the argument for including MPs: like the AttorneyGeneral, MPs arguably see the courts within their broader social and political context and may direct the commission towards more unorthodox appointments, and their inclusion further mitigates the risk of disproportionate judicial influence.

As with the previously discussed reforms, the involvement of MPs increases the risk that confidential information may be leaked. Compared with a post-appointment legislative hearing, the risk is perhaps lower here because fewer MPs are involved. While this concern still exists, it is managed and outweighed by the benefit brought by their involvement.

169 Palmer, above $\mathrm{n} 8$, at 82. Allan similarly expressed concern that the appointments commission for England and Wales would promote the appointment of "an insulated, self-selecting lawyerly caste": see Allan, above n 71 , at 81 .

170 Malleson, above n 159, at 118.

171 At 118 . 


\section{The Case for an Appointments Commission}

The foregoing discussion illustrates how several of the most common critiques of an appointments commission - that it will be captured by judges or that appointments to the commission will be politicised - can largely be mitigated by its composition. Drawing on that discussion and other considerations, this section contends that an appointments commission is the best option for New Zealand.

The primary advantage of the commission is that it enhances the political neutrality of appointments by shifting decision-making power away from a member of the government to an independent body. At present, the political neutrality of the process will inevitably be questioned, regardless of how impartial appointments are in practice, because a government minister has largely unchecked control over appointments. ${ }^{172}$ Shifting responsibility to an independent commission therefore achieves two of the main policy goals: it creates a genuine check on the Attorney-General, reducing his or her ability to stack a court with ideological appointments, and enhances the perception that this will not occur. An appointments commission is more effective in this regard than a form of committee confirmation as under that model the committee is too weak to effectively balance the Attorney-General's power over the process.

Another advantage of the commission is its transparency and inclusiveness. Legislative hearings offer transparency because they are open to the public. The transparency of an appointments commission is of a different nature; it is derived from the commission providing an inclusive, consistent process which operates independently of the government for both appointments and elevations. The existing system does not seek to elicit support for appointments from members of the legislature whose laws would eventually be reviewed. ${ }^{173}$ With a supreme law Bill of Rights this weakness becomes more significant given the risk of public resentment of the judiciary's increased power. Involving MPs is valuable because it elicits Parliament's support for appointments without creating the problems associated with legislative hearings.

Some commentators argue that a commission will not remove the risk of politicised appointments. Their concern is that a shortlist created by an advisory commission "does not diminish or curtail patronage, but 'aids and abets' it by supplying the [member of the executive] with cover to take partisan considerations into account". ${ }^{174}$ Palmer and East both expressed concern about the division of responsibility and corresponding lack of accountability that an appointments commission brings. ${ }^{175}$ It is easier to question the propriety of a discretionary appointment made by

172 See Jowell, above n 63, at 3.

173 Jowell, above n 63, at 3.

174 Gee, above n 23, at 107. Also see FC DeCoste "Political Corruption, Judicial Selection and the Rule of Law" (2000) 38 Alta L Rev 654 at 675.

175 Palmer, above n 8, at 82; and East, above n 36, at 190. 
one person than to question the decisions of an ostensibly independent commission, where the division of decision-making power means that accountability can be offloaded to others involved. ${ }^{176}$

This is a legitimate concern, but needs to be weighed against the countervailing desirability of creating a more open and inclusive appointments process. By spreading the decision-making power among a group of people, inevitably the accountability of each individual is reduced. That is the cost of a more inclusive system where the influence of one actor is balanced against that of another.

Furthermore, even if political factors did affect the Attorney-General's selection from the shortlist, the commission's value would not be wholly negated. As discussed above, complete impartiality is impossible as there are some political matters which will inevitably factor into appointments. The value of the commission is that the political element is managed and limited. An Attorney-General would not be able to stack the court with ideologically driven candidates; to be included on the shortlist, the commission must have confirmed that a candidate is well qualified. Thus, regardless of which individual is selected from the shortlist, and the reasons for that decision, the public and Parliament can be confident that the appointee is suitable.

Proponents argue that an appointments commission will increase diversity on the bench. While some commentators contend that the appointments commission for England and Wales has successfully increased diversity, ${ }^{177}$ others argue that this reform was not a panacea for increasing diversity and was "not the cure that politicians have sought". ${ }^{178}$ Given the divergence of academic opinion, increasing the diversity of the bench does not provide a strong argument either in support of or against of an appointments commission.

Nevertheless, concerns that an appointments commission will give judges undue influence and impede the appointment of unconventional candidates are mitigated by the composition and powers of the proposed commission. The inclusion of MPs and bar representatives is likely to balance judicial influence. Furthermore, the fact that the commission's responsibility is to create a shortlist rather than recommend a single name ensures greater scope for the commission to select unorthodox candidates.

176 Allan, above n 35, at 116 .

177 Baroness Prashar "Translating Aspirations into Reality: Establishing the Judicial Appointments Commission" in Judicial Appointments: Balancing Independence, Accountability and Legitimacy (Judicial Appointments Commission, 2010) 41 at 51-52.

178 Sundeep Iyer "The fleeting benefits of appointments commissions for judicial gender equality" (2013) 51 Commonwealth and Comparative Politics 97 at 117. Commenting on the appointments commission for England and Wales, Straw similarly said that "[t]he assumption regarding diversity - naïve, as it turned out - was that if we changed the process, we would change the outcome": Straw, above n 24, at 54. 
The cost and administrative burden of an appointments commission is often cited as a disadvantage. ${ }^{179}$ The appointments commission for England and Wales, responsible for nominating more than 700 judges each year, has 15 commissioners and a significant support staff. ${ }^{180}$ Its total expenditure in 2013/14 was $£ 5.59$ million. ${ }^{181}$ In contrast, New Zealand appoints about 12 judges annually. ${ }^{182}$ Yet despite the differences in size, concerns about ensuring neutrality and increasing transparency are equally important in New Zealand as in the United Kingdom.

It is indisputable that an appointments commission would impose administrative burdens on those involved, which would need to be supported with sufficient appropriations. However the low number of appointments annually eases the burden on members, most of which are already involved with appointments to some degree. ${ }^{183}$

\section{Administrative Aspects}

This section outlines some administrative matters which would contribute to the success of an appointments commission in New Zealand. The initial process could be managed by the SolicitorGeneral, as currently occurs. Similar levels of consultation, with members of the commission and those outside it, would ensure that a wide range of candidates was considered. In consultation with the members of the commission, a database of qualified candidates would be created and the primary responsibility of the commission would be reviewing this database to create a shortlist of three candidates.

Chen Palmer proposed the creation of an office within Crown Law, headed by a new Deputy Solicitor-General, to provide support on judicial appointments. ${ }^{184}$ The functions of the office would include calling for expressions of interest, holding confidential files on future candidates, managing interviews and conducting referee checks. Although this was recommended in the context of the present appointments system it could equally be adopted as the administrative and support component of an appointments commission.

There should be provision for two MPs to sit on the commission. To ensure that the MPs are seen as representing Parliament, one should be drawn from within the governing parties and one

179 Law Commission Review of the Judicature Act 1908: Towards a Consolidated Courts Act (NZLC IP29, 2012) at [3.20]

180 Law Commission, above n 179, at [3.20].

181 Judicial Appointments Commission Annual Report and Accounts (2013/14).

182 Law Commission, above n 47, at [5.22]

183 The exceptions to this are the two MPs, although the shadow Attorney-General and chairperson of the Justice and Electoral Select Committee may be consulted under the existing appointments process, see Crown Law Office, above n 36, at 6.

184 Chen Palmer \& Partners, above n 17, at [7]-[17]. 
from within the parties in opposition. The statute could provide that two MPs are to be designated members of the commission by the Prime Minister and by the Leader of the Opposition. Although it is likely that those appointed would be legally qualified, this should not be required as other experience, for example in making other public appointments, would also be valuable. Commentary on the legislation could suggest that the shadow Attorney-General and chairperson of the Justice and Electoral Select Committee should be considered for appointment first; they are obvious candidates for inclusion as both tend to be consulted during the existing judicial appointments process.

The appointments commission should operate for appointment and elevations to all courts, as was suggested in the 2004 Consultation Paper. ${ }^{185}$ Some flexibility in the commission's composition is necessary to accommodate the burden that it places on its members, so the commission's membership would partly depend on the court in which the vacancy arose. The Consultation Paper proposed a desirable degree of flexibility in recommending that in addition to the Chief Justice, the second judge involved would vary and could be the Head of the Bench of the court in which the vacancy occurs. ${ }^{186}$ The Consultation Paper also sensibly suggested that commission members could nominate another individual to take their place.

\section{CONCLUSION}

The enactment of a supreme law Bill of Rights in New Zealand would enhance the importance of judicial independence and lead to increased scrutiny of the method of appointing judges. Canada's experience after enacting the Charter indicates that New Zealand's existing appointments system will need to be reformed as the present appointments process lacks transparency, operates via an exclusive and closed-off process, and gives wide discretion to the Attorney-General, whose integrity is the main safeguard against improperly political appointments.

The latter parts of this article evaluated alternative methods of appointing judges. The Canadian case study suggests that any reform adopted must be proactive, codified, apolitical and responsive to the issues raised. Reform of judicial appointments should aim to increase public confidence in the independence and democratic legitimacy of the judiciary, provide safeguards to prevent improperly political appointments and, to reduce the risk of public attacks on the judiciary, enhance the perception that political appointments will not occur.

The foregoing discussion showed that several of the criteria by which appointments systems were assessed are in tension, for example reform that enhances independence from the government inevitably reduces accountability to Parliament. As a result, no reform will attract universal support; the reform favoured depends to an extent on which values are prioritised over others.

185 Ministry of Justice, above n 33, at [5]. See the discussion at [6]-[7] about proposed exceptions to this general process, for example for temporary appointment of former judges.

186 For Supreme Court vacancies, a second Supreme Court judge, or another Judge who was not being considered for elevation to the Supreme Court, could sit on the Commission. 
This article contends that the best option for reform is a judicial appointments commission in the form of a recommending body that supplies a shortlist of candidates to the Attorney-General. This creates a genuine check on the Attorney-General and, in doing so, enhances the perception that appointees are well-qualified and chosen based on merit. This perception will increase public confidence in the independence of the judiciary and help to protect judges from political attacks. The Attorney-General's retention of discretion and the involvement of MPs in the process enhances the democratic legitimacy of the judiciary, a particularly important feature given that judges would have the power to strike down laws passed by Parliament.

Although the present system of appointing judges has operated effectively in the current context, it is insufficiently robust to withstand the additional pressure inevitably placed upon it if a supreme law Bill of Rights were enacted. Accordingly, the adoption of a supreme law Bill of Rights should be accompanied by the creation of a judicial appointments commission in New Zealand. 